\title{
Value uncaptured perspective for sustainable business model innovation
}

\author{
Yang, $\mathrm{M}^{\mathrm{a},{ }^{*}}$; Evans, $\mathrm{S}^{\mathrm{a}}$; Vladimirova, ${ }^{\mathrm{a}}$; Rana, $\mathrm{P}^{\mathrm{a},}$ \\ ${ }^{\text {a }}$ University of Cambridge, Department of Engineering, Institute for Manufacturing, 17 Charles Babbage Road, Cambridge \\ CB3 0FS, United Kingdom \\ E-mails: my306@cam.ac.uk, se321@cam.ac.uk, dkv21@cam.ac.uk,pr296@cam.ac.uk
}

\begin{abstract}
Sustainability has become one of the key factors for long-term business success. Recent research and practice show that business model innovation is a promising approach for improving sustainability in manufacturing firms. To date business models have been examined mostly from the perspectives of value proposition, value capture, value creation and delivery. There is a need for a more comprehensive understanding of value in order to promote sustainability. This paper proposes value uncaptured as a new perspective for sustainable business model innovation, and develops four forms of value uncaptured: value surplus, value absence, value missed and value destroyed. This paper also proposes a framework of using value uncaptured for sustainable business model innovation. This framework has been validated in case studies in six product-service systems firms with advanced manufacturing technologies. The empirical studies identify 26 main sources of value uncaptured throughout the product life cycle. The findings show that (a) the new perspective of value uncaptured can help manufacturing firms understand the negative aspects of their business models; (b) the four forms and 26 sources can assist firms in identifying value uncaptured in a structured way; and (c) the identified value uncaptured can trigger the discovery of new value opportunities which lead to new business models with higher sustainable value. This paper extends the existing studies on business models from the perspectives of value proposition, capture, creation and delivery, to value uncaptured. The proposed framework has helped firms identify value opportunities that trigger the innovation of sustainable business models. Therefore, this paper contributes to both theory and practice in the field of sustainable business models innovation.
\end{abstract}

Keywords: value uncaptured; business model innovation; sustainable business models; product-service systems

\section{Introduction}

Advanced manufacturing uses emerging materials and technologies that coordinate information, computation, automation, and sensing in manufacturing to improve products or processes (Boyer et al., 1996; PCAST, 2011). Advanced manufacturing could significantly improve quality and flexibility, and at the same time reduce cost when compared to conventional manufacturing (Bülbül et al., 2013). It has the potential to influence the shape of the future of manufacturing and is essential to improving sustainability (Foresight, 2013). Technology innovation plays a key role in affecting advanced manufacturing for sustainability, because it can bring radical changes to the manufacturing process in which material, energy consumption and carbon emissions could be hugely reduced. However, technology innovation alone cannot succeed in the market (Chesbrough, 2010; Zott et al., 2011), and is unlikely to deliver sustainability (Chesbrough and Rosenbloom, 2002; Giesen et al., 2007; Girotra and Netessine, 2013). Technology always needs suitable business models to achieve its commercial potential (Chesbrough, 2010) and to improve its sustainability (Foresight, 2013). There is a growing research interest in developing new business models to improve advanced manufacturing, for example, the proposal for consumer-centric business models for additive manufacturing (Bogers et al., 2016) and focused-flexibility manufacturing systems (Copani and Urgo, 2012). There is also strong practical evidence that advanced manufacturing firms are already developing new business models to improve sustainability, for example, Tesla Motor's switching station model for electric vehicles (Girotra and Netessine, 2013) and ZETA's build-to-order model (Girotra and Netessine, 2013).

Recent research and practice show that business model innovation is a promising approach for improving sustainability in manufacturing firms. Most of the existing research on business model innovation only focuses on value proposition, value capture, creation and delivery (Amit and Zott, 2012; Richardson, 2008). Some new concepts, such as value destroyed, have emerged from recent research into business model tools, such as the Value Mapping Tool (Bocken et al., 2013; Rana et al., 2013) and Sustainable Value Analysis Tool (Yang et al., 2014). These concepts have been effectively used in sustainable business model innovation in practice; however, how they theoretically explain the innovation of business models is not well understood. The authors identify a need for a more comprehensive understanding of the value system in order to promote sustainability. This paper proposes a new perspective, value uncaptured, as a means to study business model innovation for sustainability, in the context of PSS firms with advanced manufacturing technologies. 


\section{Literature background}

Business model innovation is an emerging research area. An increasing number of researchers have seen business model innovation as a crucial part of the approach to improve sustainability for entrepreneurs and managers (Boons and Lüdeke-Freund, 2013; Girotra and Netessine, 2013). However, the field of sustainable business model innovation is still under-researched, although interest is growing (Nidumolu et al., 2009; Schaltegger et al., 2012; Wells, 2013). There is a need for a more comprehensive understanding of the value system and approaches to promote sustainable business model innovation.

\subsection{Business models}

The concept of business model first appeared in the 1950s but only became prevalent in the 1990s with the advent of the internet (Teece, 2010; Yip, 2004). Business model refers to the logic of how a firm does business (Magretta, 2002; Osterwalder and Pigneur, 2010; Teece, 2010), and describes how the firm captures, creates and delivers value (Richardson, 2008; Zott et al., 2011). Each firm has some form of business model, either explicitly or implicitly (Magretta, 2002; Reim et al., 2015; Teece, 2010). The concept of business model is closely linked to the concept of value in most business model literature. For some authors, such as Osterwalder and Pigneur, 2010, Seddon et al., 2004, and Teece, 2010, value in business models predominantly refers to business benefits (e.g. revenue, reputation, market access) and the exchange with customer benefits (e.g. functionality, health and safety, convenience). Some other authors argue that value should not only be for customers and the firm, but for all stakeholders within the value network (Magretta, 2002; Seddon et al., 2004; Zott et al., 2011). This viewpoint is becoming popular recently as supply chains become more complex, increasing the recognition that more stakeholders are involved in the value system. The recent research interest in business model largely lies on the value capture, creation and delivery. Some business model research, mainly the strategy literature, focuses on value capture, investigating how firms can capture more value than competitors, while others concentrate on new ways to create and deliver value, studying the sources of revenue (Björkdahl and Holmén, 2013).

Richardson (2008) proposed a widely accepted framework for business models, consisting of value proposition (including the offering, the target customer and differentiation strategies); value creation and delivery (including resources and capabilities, organisation and position in the value network); and value capture (including revenue sources and the economics of the business). Osterwalder et al. (2010) developed a business model canvas containing similar nine blocks: value proposition, customer segments, customer relationships, channels, key partners, key activities, key resources, cost structure and revenue streams. Boons and Lüdeke-Freund (2013) combined the approaches of various authors and suggested a generic framework composed of four elements: value proposition (the value embedded in the products/services offered by the firm); supply chain (the relationships with suppliers); customer interface (the relationships with customers); and financial model (cost and benefits, and their distribution across the stakeholders).

\subsection{Sustainable business model innovation}

Business model innovation refers to a new integrated logic of how the firm creates value for its customers or users and how it captures value, and is the implementation of a business model that is new to the firm (Björkdahl and Holmén, 2013). Contrasted with product or service innovation, business model innovation does not necessarily discover a new product or service; instead, it uses new ways to create and deliver the existing product or service, and new ways to capture value from it. Business model innovation is changing how to do business, rather than what to do, and that it goes further than purely innovations in technology, product and process (Amit and Zott, 2012). Business mdel innovation is argued to unlock the potential value from advanced technologies and transform it into market outcomes (Zott et al. 2011). Similarly, advanced technologies can also influence business model innovation (Baden-Fuller and Haefliger, 2013). The same technology through different business models will yield different market outcomes, so it is important for firms to develop capabilities to innovate business models (Chesbrough, 2010). Business model innovation has been regarded as a valuable way to bring business opportunities, however, its implementation is challenging (Chesbrough, 2010). The development of a new business model might conflict with the existing prevailing business models (Amit and Zott, 2001), and to many firms, it is even not clear what the appropriate business models ought to be (Chesbrough, 2010).

A sustainable business model is defined by Lüdeke-freund (2010) as "a business model that creates competitive advantage through superior customer value and contributes to the sustainable development of the company and society". This recognises that the core of a sustainable business is still creating and delivering customer value (Chesbrough, 2010; Osterwalder and Pigneur, 2010; Teece, 2010; Zott et al., 2011), but one in which the 
environmental and social benefits are embedded. To develop new business models for sustainability, it is essential to consider the integration of social and environmental goals into a more holistic meaning of value in business models (Schaltegger et al., 2012). A sustainable business is not only achieved through innovation in technologies, products or services, but also through business model innovation (Girotra and Netessine, 2013). Recent research shows that business model innovation has certain advantages for improving sustainability compared to technology innovation alone (Girotra \& Netessine 2013). Technology innovation is usually confined to a specific industry, while business model innovation can be applied across a wide range of industries. A company can therefore make use of business models from other sectors (Teece, 2010).

Boons and Lüdeke-Freund (2013) reviewed existing research into business model innovation for sustainability, and proposed a set of basic requirements for marketing sustainable innovations in terms of value proposition, supply chain, customer interface and financial model. Girotra and Netessine (2013) proposed a three-step approach to trigger ideas for sustainable business models. In general, the current research in the field of sustainable business model innovation is not yet mature, with a lack of agreed concepts of sustainable business models, and the ways to achieve this in practice being poorly addressed in the existing literature.

\subsection{Product-service systems (PSS) as a pioneering innovation of sustainable business models}

Some business models have higher sustainability attributes, for example, closed-loop models (Johannsdottir, 2014), industrial symbiosis (Chertow, 2007), product-service systems (PSS) (Reim et al., 2015), socially inclusive models (Nelson et al., 2009), and demand-side management models (Behrangrad, 2015). Among these, PSS has been studied by researchers from a wide range of fields and is considered as a pioneering innovation of business models for sustainability (Maxwell and Van Der Vorst, 2003; Tukker 2015; Velamuri et al., 2013).

PSS are regarded as those business models in which manufacturers sell an integration of products and services, rather than physical products alone (Goedkoop et al. 1999; Mont 2002). PSS can be classified into three types according to the ratio of services involved: product-oriented PSS (customers own products), e.g. maintenance; use-oriented PSS (providers own the products and sell the use of products), e.g. leasing; and result-oriented PSS (providers own the products and sell the results of products (Hockerts and Weaver, 2002; Tukker, 2004)). PSS is considered as a pioneering business models with high potential to achieve sustainable production and consumption (Goedkoop et al., 1999; Maxwell and Van Der Vorst, 2003; Mont, 2002; Tukker, 2015), because it could result in a total reduction of material consumption throughout the product life cycle (i.e. dematerialisation). The more a PSS moves to result-oriented, the greater potential for dematerialisation and therefore for sustainability is present (Beuren, 2013; Tukker, 2015). The reasons given are that the retaining of ownership for manufacturers would incentivise them to prolong the lifetime of products and so gain a greater long-term profit from services and end-of-life products (Baines et al., 2007). The manufacturers have more incentive to implement end-of-life strategies, such as remanufacturing and recycling, and to increase the utilisation of products (Beuren, 2013; UNEP, 2009). Longer lasting products that are re-claimed and re-used at end of useful first life are seen to be environmentally superior.

PSS business models have been implemented in industries with advanced manufacturing, such as in the automotive industry (Williams, 2006) and oil and gas industry (Bandinelli and Gamberi, 2012). A number of companies, such as GE, IBM and ABB have gained a significant proportion of their revenue from PSS business models (Martinez et al., 2010). Rolls-Royce has shifted towards providing PSS through its 'total care' packages (Neely, 2007), and its 'power by the hour' service accounted for over 50\% of its aerospace revenue (Baines et al., 2007). Xerox has shifted from being a 'photocopier manufacturer' to a 'document company', and has thus saved around 27 million US Dollars by reducing its material inputs (Xerox Corporation, 2001).

Life cycle thinking has been regarded as an essential concept to develop sustainable PSS in a holistic way (Aurich et al., 2009; Maussang et al., 2009; Roy, 2000). It seeks to identify possible solutions to improve goods and services by reducing resource use and environmental impacts throughout the entire product life cycle. The product life cycle can be divided into beginning of life (BOL), middle of life (MOL), and end of life (EOL) (Jun et al., 2007). BOL is when the product is designed and manufactured; MOL is when the product is distributed and used; EOL is when the used product is reprocessed (e.g., recycled, reused, remanufactured) and disposed. In a traditional manufacturers business model the focus is usually on value creation in BOL since selling products is their main revenue stream. The nature of PSS extends the value exchange between manufacturer and customer from BOL to MOL and even EOL, and thus brings more opportunities for value creation in MOL and EOL (Yang, 2015). For example, PSS could enable a long-term profit for manufacturers from service, allow access to data in use, and achieve an improved utilisation of product (Yang et al., 2013). This motivates servitizing manufacturers to identify new opportunities for value creation in MOL and EOL (Toossi, 2011). 


\section{Theoretical framework: value uncaptured perspective for sustainable business model innovation}

The literature identifies the need for approaches to promote sustainable business model innovation. The authors' previous research, such as (Rana et al., 2013), shows that companies were able to identify new business opportunities by mapping value proposition, value destroyed and value missed among multiple stakeholders. This rationale has been found to be helpful in understanding value exchange between stakeholders and for stimulating new business models (Bocken et al., 2013). The concepts of value destroyed and value missed were further developed, and two new concepts - value surplus and value absence - were proposed to study the value system across product life cycles (Yang et al., 2014). The four concepts were then juxtaposed to uncover any shared conceptual basis. That shared base is termed by the authors 'Value uncaptured' and defined as the potential value that could be captured but has not yet been captured. Value uncaptured exists in almost all companies. Some value uncaptured is visible, e.g. waste streams in production, co-products, under-utilised resources, and reusable components of broken products, while often it is invisible, e.g. over capacity of labour, insufficient use of expertise and knowledge.

This paper proposes a framework that uses the concept of Value uncaptured as a new perspective for sustainable business model innovation, shown in Figure 1. The logic behind the framework is that sustainable business model innovation can be more easily achieved by identifying the value uncaptured in current business models, and then turning this new understanding of the current business into value opportunities that can lead to new business models with higher sustainable value.

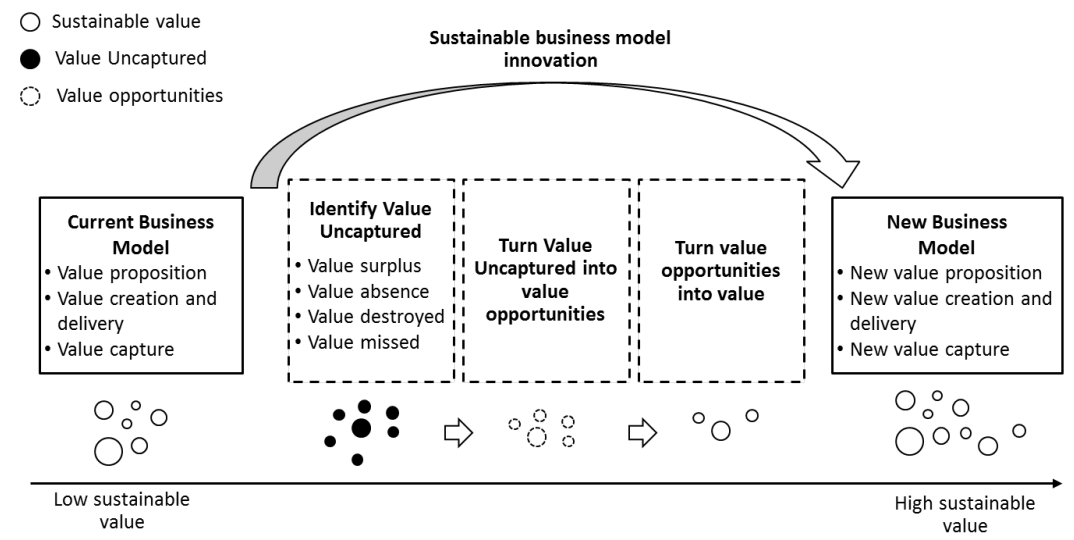

Figure 1. Framework of using value uncaptured for sustainable business model innovation

Before developing new business models, it is important for actors to understand their current business model. In this framework, the current business model is represented by the current value proposition, value creation and delivery, and value capture, i.e. what and how a firm creates and delivers value to its stakeholders, and how the firm captures value from it. This understanding extends the widely accepted business model framework proposed by Richardson (2008) to a wider scope. Firstly, the value is not only for customers and the firms, but for all stakeholders, such as end users, suppliers, shareholders, government and partners. Secondly, the value covers not only monetary value, but also wider value for the environment and for society. For example, improved energy efficiency, zero carbon emissions and cleaner production are regarded as value created and delivered for the environment.

This framework proposes that identifying value uncaptured in the current business model can trigger business model innovation for sustainability. In order to better understand the concept of value uncaptured, this paper develops the four forms of value uncaptured from previous work (Yang et al., 2014) shown in Figure 2.

Value uncaptured: the potential value that could be captured but has not been captured.

- Value surplus - value which exists, but is not required.

- Value absence - value which is required, but does not exist.

- Value missed - value which exists and is required, but is not exploited.

- Value destroyed - value with negative consequences. 
- Value surplus (VS) is value which exists, but is not required. These are things or activities that are more than needed. They are redundant and unnecessary. They can be regarded as waste in a company or unnecessary value delivered to stakeholders. The concept of VS is similar to waste but embodies a broader meaning. It includes not only tangible waste but also intangible waste, such as underutilisation of human resource. It offers higher potential to be turned into value. It exposes avoidable resource consumption and cost. Examples could be wasted heat, waste energy, over production, underutilisation of resources, and unnecessary, repeated work.

- Value absence (VA) is value which is required, but does not exist. They are things or activities that are needed but have not been provided. It can be regarded as needs that could have been met but have not yet been met; or as a lack of resource that is needed by the company or its stakeholders. For example this could be a temporary lack of labour, the need for recycling service, the need for experts in certain fields, or the need for a platform. A specific example could be that there is a temporary need for additional warehouse space and workers due to increased production, but the company may not be inclined to buy extra warehouse space or to hire new employees just for this short busy period. In this case, the need for additional warehousing and labour can be regarded as a value absence.

- Value missed (VM) is value which exists and is required, but is not exploited. It could create more value but it does not. It is currently squandered or inadequately captured by the current business model. It can be regarded as waste with high potential to be used. It does not bring about negative outcomes but it reduces value that could be created. Examples are underutilisation of by-products and co-products, underutilised assets and resources, and inefficient use of human resources.

- Value destroyed (VD) is value with negative consequences. It causes negative effects for the company or other stakeholders, and is the negative outcome of the current business model. It can be seen as damage to the planet, people and profits. In the context of sustainability, value destroyed refers particularly to damage to the environment and to society. Examples include depletion of non-renewables, pollution, poor product and service quality, bad working conditions and health and safety problems.

In this framework, value opportunities are any activities that can capture, create and deliver new value to the firm and its stakeholders. They can be regarded as potential solutions to reduce the negative forms of value or to turn them into positive forms of value. As shown in Figure 1, not all value uncaptured is guaranteed to be turned into value opportunities and not all value opportunities can be implemented and turned into value. However, the identification of value uncaptured is intended to trigger the discovery of new value opportunities which leads to innovation of the business model. This is the main novelty of this framework: using negative forms of value to stimulate the identification of negative aspects of the current business model, and directly inspire the identification of value opportunities.

\section{Research method}

This research adopts multiple case studies method (Yin, 2009) to study the concept of value uncaptured for sustainable business model innovation within the real-life context of PSS companies with advanced manufacturing. The case studies method is chosen for this research because this method is best suited for studying a complex, contemporary phenomenon with few existing theories (Bryman and Bell, 2015; Yin, 2009). As mentioned before, business model innovation is an emerging field with few existing theories, and it has not yet reached a mature stage and thus, the most suitable approach for investigation is case studies.

The cases for this research were selected following a sampling strategy where the companies need to be manufacturing companies having transformed or are transforming towards PSS business models; where they have the awareness to improve sustainability; and they cover more than five industrial sectors and more than three countries. The required number of cases for research depends on the degree of saturation of new information (Eisenhardt, 1989). Following the sampling guidance, six case studies were selected for this research. The case studies included 25 semi-structured interviews and workshops, during which 56 industrial participants actively engaged in identifying the value uncaptured in terms of sustainability in their companies. Data were collected from multiple sources: documentation (e.g. company reports, newspaper articles and project reports), observation, and transcripts of interviews and workshops. An overview of the data collection is presented in Table 1. 


\begin{tabular}{|c|c|c|c|}
\hline & Industries & Data gathering & Interviewees/participants \\
\hline \multirow{10}{*}{$\begin{array}{c}\text { Case } \\
\text { study } \\
\text { A }\end{array}$} & \multirow{10}{*}{$\begin{array}{l}\text { Country: China } \\
\text { Industries: } \\
\text { Large equipment } \\
\text { manufacturing } \\
\text { industry (air } \\
\text { separation unit) }\end{array}$} & \multirow{10}{*}{$\begin{array}{l}\text { Data source: } 10 \text { interviews and workshop } \\
\text { transcripts; workshop notes; observation; } \\
\text { company reports } \\
\text { Description: The company is transforming its } \\
\text { business models from selling gas generators to } \\
\text { gas as a service. }\end{array}$} & Director of a design institute \\
\hline & & & Two designers from a design institute \\
\hline & & & $\begin{array}{l}\text { Deputy general manager, company } \\
\text { secretary, securities director. }\end{array}$ \\
\hline & & & Manager of a security department \\
\hline & & & Deputy director of a design institute \\
\hline & & & $\begin{array}{l}\text { Head of design projects, project } \\
\text { engineer }\end{array}$ \\
\hline & & & Designer of traditional projects \\
\hline & & & $\begin{array}{l}\text { Investment manager of gas investment } \\
\text { department }\end{array}$ \\
\hline & & & Three designers of gas projects \\
\hline & & & Two designers of traditional projects \\
\hline \multirow{6}{*}{$\begin{array}{c}\text { Case } \\
\text { study } \\
\text { B }\end{array}$} & \multirow{6}{*}{$\begin{array}{l}\text { Country: China } \\
\text { Industries: } \\
\text { Large equipment } \\
\text { manufacturing } \\
\text { industry (steam } \\
\text { turbines) }\end{array}$} & \multirow{6}{*}{$\begin{array}{l}\text { Data source: six interviews and workshop } \\
\text { transcripts; workshop notes; observation; } \\
\text { company reports } \\
\text { Description: The company is transforming its } \\
\text { business models from selling steam turbines to } \\
\text { electricity as a service. }\end{array}$} & General manager \\
\hline & & & Deputy general manager \\
\hline & & & Supply chain manager \\
\hline & & & Manager of computing institute \\
\hline & & & General manager and 20 employees \\
\hline & & & $\begin{array}{l}\text { Industrial turbine academy, head of } \\
\text { integrated management office, senior } \\
\text { engineer }\end{array}$ \\
\hline \multirow{3}{*}{$\begin{array}{l}\text { Case } \\
\text { study } \\
\text { C }\end{array}$} & \multirow{3}{*}{$\begin{array}{l}\text { Country: China } \\
\text { Industries: } \\
\text { Digital Video } \\
\text { Recorders }\end{array}$} & \multirow{3}{*}{$\begin{array}{l}\text { Data source: three interviews and workshop } \\
\text { transcript; company reports; workshop notes. } \\
\text { Description: The company is transforming its } \\
\text { business models from selling video } \\
\text { surveillance equipment to an integrated } \\
\text { solution as a service. }\end{array}$} & $\begin{array}{l}\text { Senior technical support manager, } \\
\text { image processing and analysis division } \\
\text { director, solutions director }\end{array}$ \\
\hline & & & Industry development manager \\
\hline & & & Senior technical support manager \\
\hline \multirow{3}{*}{$\begin{array}{l}\text { Case } \\
\text { study } \\
\quad D\end{array}$} & \multirow{3}{*}{$\begin{array}{l}\text { Country: China } \\
\text { Industries: } \\
\text { Large equipment } \\
\text { manufacturing } \\
\text { industry } \\
\text { (Turbo-machiner } \\
\text { y) }\end{array}$} & \multirow{3}{*}{$\begin{array}{l}\text { Data source: one direct interview transcript } \\
\text { and two secondary interview transcripts; } \\
\text { Company reports, company documents } \\
\text { Description: The company is currently having } \\
\text { various PSS business models and has achieved } \\
\text { huge growth in revenue since the } \\
\text { implementation of PSS. }\end{array}$} & $\begin{array}{l}\text { Executive vice director and senior } \\
\text { engineer }\end{array}$ \\
\hline & & & Strategy planning director \\
\hline & & & Strategy planning vice director \\
\hline \multirow{2}{*}{$\begin{array}{l}\text { Case } \\
\text { study } \\
\text { E }\end{array}$} & \multirow{2}{*}{$\begin{array}{l}\text { Country: UK } \\
\text { Industries: Fuel } \\
\text { cell cars }\end{array}$} & \multirow{2}{*}{$\begin{array}{l}\text { Data source: two interview transcripts. } \\
\text { Description: This is a start-up, fuel cell car } \\
\text { company selling mobility rather than cars, e.g. } \\
\text { charging the miles travelled rather than cars }\end{array}$} & Founder and CEO \\
\hline & & & Founder and CEO \\
\hline $\begin{array}{l}\text { Case } \\
\text { study } \\
\text { G }\end{array}$ & $\begin{array}{l}\text { Country: US } \\
\text { Industries: } \\
\text { Large equipment } \\
\text { manufacturing } \\
\text { industry (Power } \\
\text { Generator) }\end{array}$ & $\begin{array}{l}\text { Data source: one interview transcript, two } \\
\text { indirect interview transcripts, company reports, } \\
\text { company documents. } \\
\text { Description: The company provides various } \\
\text { energy solutions as services. }\end{array}$ & Manufacturing manager \\
\hline
\end{tabular}

In the interviews and workshops, the industrial participants were asked to define the detailed stages of their product life cycle, and then to identify the value uncaptured in each of these stages. This process needed substantial knowledge and experience, and required facilitated brainstorming to provide guidance and inspiration. Prompts and practical examples were provided during the process.

Qualitative data analysis methods (Miles and Huberman, 1994) was used to analyse the data. The data analysis process was mainly conducted using MAXQDA software to manage a large volume and variety of qualitative data. This study undertook three stages of coding: open coding (i.e. read the data, note down codes for related statements and assign them to categories), axial coding (i.e. re-read data, identify statements that fit into any 
codes or categories), and looking for explanation and patterns in coding. The data relating to the source of value uncaptured was analysed and 464 codes of value uncaptured emerged from the data. Memos were written about each code.

\section{Empirical findings}

The 464 codes of value uncaptured were clustered into common themes and categorised. The analysis generated 26 main sources of value uncaptured across the product life cycle of the six manufacturing companies, shown in Table 2. Then, Table 3, 4, and 5 show the specific details of each of the 26 sources in BOL, MOL and EOL.

Table 2. Main sources of value uncaptured across the product life cycle

\begin{tabular}{|l|l|l|}
\hline \multicolumn{1}{|c|}{ BOL-VU } & \multicolumn{1}{|c|}{ MOL-VU } & \multicolumn{1}{c|}{ EOL-VU } \\
\hline - Design & $\begin{array}{l}\text { - Customers' value uncaptured } \\
\text { - Human resources }\end{array}$ & \\
- Production & - Operations management & \\
- Operations & - Service data & \\
- Cunagement & - Co-products or by-products & \\
- Human resources & - Products' products & - Recycle \\
- Contracts & - Customer needs & - Reuse \\
- R\&D & - Need for a platform & Remanufacture \\
- Finance & - Delivery & \\
- Planning & - Conflicts over service & \\
- Knowledge \& & contracts & \\
technology & - Risks & \\
\hline
\end{tabular}

(Note: The sources of value uncaptured are ordered in terms of their frequency, i.e. the times mentioned by the interviewees in total.)

\subsection{Value uncaptured at the beginning of life (BOL-VU)}

Table 3 presents the details of each main source of value uncaptured at BOL. Each type of value uncaptured was generalised from a number of real examples from case studies.

Table 3. Main sources of value uncaptured at BOL

\begin{tabular}{|l|l|}
\hline \multicolumn{2}{|c|}{ BOL-VU } \\
\hline Sources & \multicolumn{1}{|c|}{ Details } \\
\hline \multirow{5}{*}{ Design } & - Redundant design \\
& - Insufficient design \\
& - Excess design \\
& - Row design efficiency \\
& - Design too early \\
& - Poor design quality \\
& - Poor system of rewards and penalties for designers \\
& - Lack of method for new designs \\
& - Lack of new design thinking (e.g. life cycle thinking, sustainability) \\
& - Poor communication between designers and manufacturers \\
& - Not use of service data to improve design \\
\hline \multirow{5}{*}{ Production } & - Over procurement or too early procurement \\
& - Poor production technology \\
& - Pollution (e.g. noise) \\
\hline
\end{tabular}




\begin{tabular}{|c|c|}
\hline $\begin{array}{l}\text { Operations } \\
\text { management }\end{array}$ & $\begin{array}{l}\text { - Poor flexibility } \\
\text { - Bad mechanism for assessing rewards and penalties } \\
\text { - Bad project time management } \\
\text { - Inefficient inter-department collaboration and resource sharing } \\
\text { - Poor execution ability } \\
\text { - Insufficient use of information management systems } \\
\text { - Reluctance to adopt new management systems } \\
\text { - Unable to adapt to new technology and products } \\
\text { - Inefficient workflow }\end{array}$ \\
\hline Customer needs & $\begin{array}{l}\text { - Unknown potential customers } \\
\text { - Potential customer needs } \\
\text { - Future customer needs } \\
\text { - Unclear customer needs } \\
\text { - Overpromising to meet customer needs } \\
\end{array}$ \\
\hline Human resources & $\begin{array}{l}\text { - Excess capacity of managers, designers, production workers } \\
\text { - Lack of excellent human resources } \\
\text { - Insufficient and inefficient use of labour }\end{array}$ \\
\hline Contract & $\begin{array}{l}\text { - Low-profit contracts } \\
\text { - Unclear service contracts }\end{array}$ \\
\hline R\&D & $\begin{array}{l}\text { - Lack of R\&D in basic scientific research } \\
\text { - Lack of R\&D into products' products } \\
\text { - Lack of IP protection }\end{array}$ \\
\hline Finance & - High initial investment and low profits \\
\hline Planning & - Unclear strategic plan \\
\hline $\begin{array}{c}\text { Knowledge \& } \\
\text { technology }\end{array}$ & $\begin{array}{l}\text { - Lack of knowledge and technologies } \\
\text { - Wasted knowledge, technology, experience and skills }\end{array}$ \\
\hline
\end{tabular}

In BOL, most of the value uncaptured was identified in design. Most of the interviewees emphasised that design played a key role because it influences the value creation throughout the entire product life cycle. Various types of value uncaptured were found to exist in design, for example redundant design, repeated design, and over design. Each type of value uncaptured was generalised from a number of real examples from case studies, for instance, redundant design was generated from the examples of excessive consideration of future customer needs and safety issues in design. Companies' inefficient management system were considered as the root cause of other value uncaptured, such as waste of human resource, and therefore improving the management system should contribute to solving some of these problems. High potential value was identified from contract making, but it was regarded as the most challenging area as it requires skilful and subtle negotiations with customers. This was especially the case in Company A, which was transitioning from selling gas machines into selling industrial gases, as customers needed to be convinced in order for the change to work well. The Investment Manager of this company described the contract making process with customers as 'a fight and a battle of wits and courage'.

\subsection{Value uncaptured at the middle of life (MOL-VU)}

Table 4 presents the details of each main source of value uncaptured at MOL.

Table 4. Main sources of value uncaptured at MOL

\begin{tabular}{|c|l|}
\hline \multicolumn{2}{|c|}{ MOL-VU } \\
\hline Sources & \\
\hline & - Customers' wasted resources \\
& - Customers' waste from products, co-products \& by-products \\
& - Customers' unprofessional use of products \\
Customers' value & - Customers' pollution \\
uncaptured & - Customers'poor ability in identifying value uncaptured \\
& - Customers' missed applications for products \\
& - Customers' production waste \\
& - Customers' pollution \\
\hline
\end{tabular}




\begin{tabular}{|c|c|}
\hline Human resource & $\begin{array}{l}\text { - Excess capacity of service workers } \\
\text { - Insufficient and inefficient use of service workers } \\
\text { - Lack of excellent human resources } \\
\text { - Inefficient communication between workers } \\
\text { - Repeated work }\end{array}$ \\
\hline $\begin{array}{l}\text { Operations } \\
\text { management }\end{array}$ & $\begin{array}{l}\text { - Lack of regulations for operational management } \\
\text { - Inefficient workflows (e.g. time, money and human resources wasted in } \\
\text { workflows) } \\
\text { - Service scheduling problems } \\
\text { - Unnecessary waste in operations } \\
\text { - Poor flexibility } \\
\text { - Low operational efficiency } \\
\text { - Poor mechanism for rewards and penalties } \\
\text { - Poor execution ability } \\
\text { - Inefficient inter-department collaboration and resource sharing } \\
\text { - Inefficient communication between service workers, designers and producers }\end{array}$ \\
\hline Service data & $\begin{array}{l}\text { - Lack of technology, expertise and knowledge on using data } \\
\text { - Inefficient and insufficient use of service data (done manually) } \\
\text { - Missed value from historical service data relating to existing customers } \\
\text { - Inefficient service arrangements } \\
\text { - Limited access to some services }\end{array}$ \\
\hline $\begin{array}{l}\text { Co-products or } \\
\text { by-products }\end{array}$ & $\begin{array}{l}\text { - Insufficient use of co- and by-products } \\
\text { - Unknown applications for co- and by- products } \\
\text { - Unable to use co- and by- products }\end{array}$ \\
\hline Products' products & $\begin{array}{l}\text { - Missed applications for products' products } \\
\text { - Unknown applications for products' products }\end{array}$ \\
\hline Service & $\begin{array}{l}\text { - Excess service (e.g. unnecessary services, idle service workers, too much } \\
\text { investment inn service resources) } \\
\text { - Poor service effectiveness and efficiency } \\
\text { - Missed service opportunities } \\
\text { - Lack of service experience } \\
\text { - Service scheduling problems (e.g. who, when and how many workers to send) } \\
\text { - Invalid services } \\
\text { - No calculation or control of service cost } \\
\text { - Poor service quality } \\
\text { - Low service charges } \\
\text { - Lost or missed business opportunities during service } \\
\text { - Inefficient allocation of service personnel } \\
\text { - Service tasks too detailed } \\
\text { - Ineffective service evaluation system }\end{array}$ \\
\hline Customer needs & $\begin{array}{l}\text { - Unknown customer needs (e.g. real needs, potential needs, hidden needs and } \\
\text { future needs) } \\
\text { - Inaccurate understanding of customer needs } \\
\text { - Changes in customer needs } \\
\text { - Unclear customer needs }\end{array}$ \\
\hline Need for a platform & $\begin{array}{l}\text { - Need for a platform to sell the collected waste } \\
\text { - Need for a platform to enter new industrial sectors }\end{array}$ \\
\hline Delivery & $\begin{array}{l}\text { - Delays in delivery } \\
\text { - Missing components in packaging } \\
\text { - Sending wrong products or components } \\
\text { - Late deliveries }\end{array}$ \\
\hline $\begin{array}{l}\text { Conflicts over } \\
\text { service contracts }\end{array}$ & - Difficulty in judging responsibilities in relation to service contracts \\
\hline Risks & $\begin{array}{l}\text { - Market risks } \\
\text { - Policy risks } \\
\text { - Risks of crossing into other industrial sectors }\end{array}$ \\
\hline
\end{tabular}




\begin{tabular}{|c|l|}
\hline \multirow{4}{*}{$\begin{array}{c}\text { Waste of resource } \\
\text { and energy }\end{array}$} & $\begin{array}{l}\text { - Waste of mechanical work } \\
\text { steam) }\end{array}$ \\
& $\begin{array}{l}\text { - Underutilised resources (e.g. underutilised assets) } \\
\text { - Oil leaks }\end{array}$ \\
& $\begin{array}{l}\text { Lack of freedom to use all this waste since it needs agreement from the } \\
\text { customer }\end{array}$ \\
\hline \multirow{2}{*}{ Others } & $\begin{array}{l}\text { - Unexpected problems during service } \\
\text { - Pressure from retailers }\end{array}$ \\
\hline
\end{tabular}

In MOL, there is a wide range of sources of value uncaptured. It was found that in PSS companies, customers' value uncaptured was the type mentioned most frequently. Many potential value opportunities were identified from products' products (where the PSS provider can help their direct customer improve what is delivered to their end customer), e.g. the application of gases in new fields, the new source of wasted heat that could generate electricity. Most of the interviewees found that this type of value uncaptured was not often recognised by customers. This was because the manufacturer is more professional than its customers at dealing with products' products and could be better at capturing value in these areas. This is interesting because customers' value uncaptured would not have even been considered when the manufacturer was just selling machines in the traditional way. For example, investigating new applications for gases did not become an area of interest for Company A until the company was transitioning from selling gas machines into selling industrial gases, and now it is a significant future focus for the company and it triggered the company to enter new industrial fields. This implies that PSS business models could activate certain value uncaptured in MOL which would not be recognised in traditional business models. The identified value uncaptured could trigger new opportunities for value creation, and therefore lead to the innovation for business models.

Customer needs were also regarded as a key value uncaptured in MOL. The value uncaptured of customer needs included unknown or unclear customer needs (such as real need, potential need, hidden need and future need), changes of customer needs, and inaccurate understanding of customer needs. A poor understanding of customer needs caused unnecessary operational waste in these companies. This causes huge waste for both the manufacturer and its customers. However, determining actual customer requirements was challenging. One reason is that customers' service needs are usually complex, intangible and variable. PSS business models could provide companies with more opportunities to communicate with its customers and to understand their needs.

Several types of value uncaptured in MOL are related to service, such as service data, low service effectiveness and efficiency, and over provision of service. Service data was considered an important value uncaptured. PSS business models had enabled the manufacturers to access service data. Advanced manufacturing had offered the infrastructure, such as information technology, automation and sensing, to collect service data from their customers' sites almost in real time. The service data was still not yet utilised due to the lack of expertise, knowledge and skills of data analysis. It was recognised that there is huge potential to create value from the service data.

\subsection{Value uncaptured at the end of life (EOL-VU)}

Relatively few codes relating to EOL-VU were identified from the six cases. These were categorised into three main types as shown in Table 5.

Table 5. Main sources of value uncaptured at EOL

\begin{tabular}{|l|l|}
\hline \multicolumn{2}{|c|}{ EOL-VU } \\
\hline Sources & \\
\hline \multirow{5}{*}{ Recycle } & - No or little recycling \\
& - Lack of awareness and knowledge of recycling \\
& - Valuable materials in discarded products \\
& - Low-value disposal of recycled products \\
& - No customer demand for recycling \\
&
\end{tabular}




\begin{tabular}{|c|l|}
\hline \multirow{4}{*}{ Reuse } & - Idle, usable, re-purchased old products \\
& - Insufficient use of usable old products \\
& - Usable products discarded by customers \\
& - Low-value disposal of usable products and components \\
& - Poor customer acceptance of reuse of products \\
\hline \multirow{5}{*}{ Remanufacture } & - No or little remanufacturing \\
\hline & - Lack of awareness and knowledge of remanufacturing \\
& - Lack of capacity to undertake remanufacturing \\
& - No customer demand for remanufacturing \\
& - Low acceptance by customer of remanufactured products \\
\hline
\end{tabular}

Little data was collected at the EOL stage since the interviewed companies had poor awareness and knowledge concerning this stage of the product life cycle. This reflects the fact that not many manufacturing companies have considered value at the EOL stage.

\section{Discussion}

The empirical study brings new insight into how value uncaptured can be used as a new perspective for sustainable business models. The concept of value uncaptured, the proposed framework and the empirical findings are discussed as below.

\subsection{The concept of 'value uncaptured'}

To date, business models are examined mostly from the perspective of value proposition, value creation and delivery, and value capture (e.g. Richardson, 2008). However, these perspectives only explain how, what and with whom the value is exchanged, but do not fully explain how much and/or to what extent the value is exchanged. There is a need for a more comprehensive understanding of this central component of business models. This paper used the concept of value uncaptured $(V U)$ to represent failed value exchanges in a business model. This concept improves our understanding of value systems in business models, and their use by practitioners can improve business model innovation.

It should be noted that value uncaptured in this study is not related to the concept of value capture in most business model literature. Value uncaptured is 'the set of benefits that could be captured but have not yet been captured'. Value capture in literature is defined as 'how the firm generates revenue and profit' and it includes 'revenue sources' and 'the economics of the business' (Richardson, 2008). The proposed concept of value uncaptured encompasses much broader concerns than value capture in terms of what (e.g. it is not only concerned with revenue) and with whom (e.g. not only with customers), and to what extent the value is exchanged.

In terms of the four forms of value uncaptured (value surplus, value absence, value missed and value destroyed), the findings reveal that this novel structuring of value was helpful in inspiring practitioners to identify examples of value uncaptured in their companies. However, it was occasionally difficult to separate them during data analysis. Overlaps were found between some forms, such as value surplus and value missed, and value absence and value missed. Furthermore, cause-and-effect relationships existed between some value forms across different timelines and aspects of sustainability. For example, some value destroyed in MOL was caused by the value absence in BOL (e.g. noise produced at the use phase of machines is sometimes caused by a lack of quality consideration at the production stage); and some economic value resulted in environmental value destroyed (e.g. using cheap, non-environmental technology sometimes saves money but damages nature). The data shows that there are interesting patterns and relationships across the four forms of value uncaptured, and suggests there is a need to investigate this in the future.

\subsection{The 26 sources of value uncaptured and Seven Wastes of lean production}

All six cases show that it is often difficult for manufacturers to identify value uncaptured across their product life cycle especially at the MOL and EOL stages. The reason is that they have seldom considered the potential value in MOL and EOL previously, and that some value uncaptured is more likely to be invisible at these stages, such as inefficient allocation of service personnel. The four forms and 26 sources of value uncaptured provide a strategic checklist for companies to identify the value uncaptured in their companies. These sources of value 
uncaptured may be common in many other manufacturing firms and could be used to guide and inspire practitioners to identify specific value uncaptured in their firms. Table 3, 4, and 5 provide comprehensive ways of considering value uncaptured at BOL, MOL and EOL. For example, Table 3 includes detailed aspects of value uncaptured in the area of design, e.g. redundant design, insufficient design, designing too early and lack of design theory. These could play the role of a checklist to help companies examine if they also have similar types of value uncaptured in their companies, and inspire them to look for opportunities to turn value uncaptured into value.

It is interesting to find that in all the case studies, the example of Seven Wastes of lean production (Bicheno and Holweg, 2008), also known as TIM WOOD (i.e. transport, inventory, motion, waiting, overproduction, over-processing and defects), was very helpful in inspiring practitioners to identify value uncaptured in production. Similar to the Seven Wastes, which have helped numerous factories identify wastes in production, the 26 sources of value uncaptured, as well, have been proven to be helpful to manufacturers in identifying 'value that has not been captured' across the entire produce life cycle. The concept of value uncaptured is broader than Seven Wastes, and covers much more stages of the product life cycle (not only in production). There are no existing, generic frameworks, like the Seven Wastes of lean production, for other stages of the product life cycle, in particular for MOL and EOL. Therefore, the 26 sources contribute to this and build a broader list for value uncaptured across product life cycle.

Looking back at the history of lean production, the Seven Wastes were generated from almost half a century of production data from Toyota, while the theory of lean production was created from a five-year study conducted by a group of researchers and practitioners from 17 countries (Womack et al., 1990). By now, a large number of manufacturers in the world have benefited from the concept of lean production. The way in which the Seven Wastes were generated suggests that it should be possible to use empirical data to generate a list of value uncaptured that is common across manufacturing companies. This list should then be able to guide manufacturers to identify value uncaptured in their own companies. It also indicates that the study conducted here might only be the start of a journey involved in creating such a value uncaptured list. This is a promising research direction with the potential to make a significant industrial impact.

\subsection{Using value uncaptured for sustainable business model innovation}

The concept of value uncaptured brings a new perspective to look at value systems in business models. The authors also set out to study how this concept could be used for sustainable business model innovation. Identifying value uncaptured is shown to help companies in understanding the negative aspect of their business models, i.e. failed exchanged value. The identified value uncaptured can trigger the discovery of new opportunities for value creation, capture and delivery, and therefore lead to innovation for business models. In the context of sustainability, the value not only includes economic value, but also environmental and social value. The findings reveal that using value uncaptured can assist manufacturing companies to promote sustainability.

All six companies found the concept of value uncaptured useful and that it effectively helped them to identify value opportunities. For example, Case A identified 152 value opportunities, although some overlapped and some might not be feasible. The identification of value uncaptured was occasionally difficult especially in relation to services since it was usually invisible or hidden. The four forms of value uncaptured can help industrial practitioners to identify value uncaptured in a structured and comprehensive way. For example, Case Study A identified 29 types of value uncaptured generated from 222 codes; of these, 121 codes were identified at the MOL stage where service played a major part. Many interviewees had positive feedback on the categorisation of the four forms of value uncaptured. For instance, the founder of Company E commented that the 'analytical approach to value' and 'the breakdown of forms of value' was very interesting and helpful.

\subsection{Value uncaptured in PSS business models}

The cases show that the different types of value uncaptured are of varying importance for different business models. For example, inefficient management systems is a common value uncaptured for most companies, while some value uncaptured, such as products' products, were only important for certain PSS business models. Products' products were a major value uncaptured in result-oriented PSS but were less important in product-oriented PSS in which customers control the products' products and companies are unlikely to capture value from them. It might be because that such value uncaptured are 'locked in' in product-oriented PSS but 'released' in result-oriented PSS. 
All cases show that by transforming their business model to that of PSS, the companies identified value uncaptured which had not been considered before the transformation. It indicates that this value uncaptured was hidden within traditional business models but uncovered within PSS business models. This value uncaptured could offer high potential for creating sustainable value for both manufacturers and customers. However, these are early results and identification of value uncaptured in MOL has rarely been investigated by researchers and practitioners. This implies a gap in this research field and further confirms the need for this research.

\section{Conclusions and implications}

This paper contributes to theory by proposing the concept of value uncaptured and offers a framework for using it as a novel perspective for sustainable business model innovation. Four forms of value uncaptured are used to trigger innovation: value surplus, value absence, value missed and value destroyed. In the context of sustainability, each value is considered not only from the perspective of economic value, but also from the perspectives of environmental and social value. The concept of value uncaptured extends the commonly accepted understanding of value system in business model research, i.e. value proposition, value creation and delivery, and value captured, to a wider scope. The framework proposes that by identifying the value uncaptured in their current business models, firms could turn this understanding into value opportunities which lead to a new business model with higher sustainable value. The identification of value uncaptured was observed to trigger the discovery of new value opportunities which led to innovation of the business model. The novelty of this framework is to use negative forms of value to stimulate the identification of negative aspects of the current business model and trigger the innovation of positive business models. It implies that researchers in the field of business models can use this perspective to study value exchange in business models especially failed value exchanges, in addition to the existing value perspectives found in business model literature.

This paper provides empirical evidence for value uncaptured in six product-service systems companies with advanced manufacturing technologies. The research has identified 26 sources of value uncaptured throughout the product life cycle based on empirical data. These sources offer the potential to have a significant impact on understanding value in industry and for further research in this area.

The findings show that the perspective of value uncaptured can effectively assist companies in understanding the negative aspects of their current business model and also in transforming the value uncaptured into value opportunities. The 26 sources of value uncaptured can provide a structured approach for guiding industrial practitioners to identify value uncaptured in their companies. These sources could play a similar role to the Seven Wastes of lean production, but in the context of the entire product life cycle rather than just in production. The 26 sources have the potential to inspire practitioners to consider the intangible value uncaptured across each stage of the product life cycle, particularly in MOL and EOL which are usually neglected by manufacturers. However, the key sources of value uncaptured might vary for different companies and at different time. This implies that practitioners can further identify detail sources of value uncaptured (based on the 26 sources) for their own companies.

\section{Acknowledgements}

This paper builds on the work undertaken on the UK EPSRC Centre for Innovative Manufacturing in Industrial Sustainability (EP/I033351/1), Europe-China High Value Engineering Network (EC-HVEN) (PIRSES-GA-2011-295130), the EPSRC Business Models for Sustainable Industrial Systems (BM4SIS) (EP/L019914/1), and "SustainValue" project funded by the European Community's Seventh Framework Programme (FP7/2007-2013).

\section{Reference}

Amit, R. and Zott, C. (2001), "Value creation in e-business", Strategic Management Journal, Vol. 22 No. 6-7, pp. 493-520.

Amit, R. and Zott, C. (2012), "Creating value through business model innovation”, MIT Sloan Management Review, Vol. 53, pp. 41-49.

Aurich, J., Wolf, N., Siener, M. and Schweitzer, E. (2009), "Configuration of product-service systems", Journal of Manufacturing Technology Management, Vol. 20 No. 5, pp. 591-605.

Baden-Fuller, C. and Haefliger, S. (2013), "Business models and technological innovation”, Long Range Planning, Vol. 46 No. 6, pp. 419-426. 
Baines, T.S., Lightfoot, H.W., Evans, S., Neely, A., Greenough, R., Peppard, J., Roy, R., et al. (2007), "State-of-the-art in product-service systems", Proceedings of the Institution of Mechanical Engineers Part B Journal of Engineering Manufacture, Vol. 221 No. B, pp. 1543-1552.

Bandinelli, R. and Gamberi, V. (2012), "Servitization in oil and gas sector: outcomes of a case study research", Journal of Manufacturing Technology Management, Vol. 23 No. 1, pp. 87-102.

Behrangrad, M. (2015), "A review of demand side management business models in the electricity market”, Renewable and Sustainable Energy Reviews, Vol. 47, pp. 270 - 283.

Beuren, F. (2013), "Product-service systems: a literature review on integrated products and services", Journal of Cleaner Production.

Bicheno, J. and Holweg, M. (2008), The Lean Toolbox: The Essential Guide to Lean Transformation, Picsie Books, 4th editio.

Björkdahl, J. and Holmén, M. (2013), "Editorial: business model innovation - the challenges ahead", International Journal of Product Development, Vol. 18 No. 3, pp. 213-225.

Bocken, N.M.P., Short, S.W., Rana, P. and Evans, S. (2013), “A value mapping tool for sustainable business modelling”, Corporate Governance, Vol. 13 No. 5, pp. 482-497.

Bogers, M., Hadar, R. and Bilberg, A. (2016), "Additive manufacturing for consumer-centric business models: Implications for supply chains in consumer goods manufacturing”, Technological Forecasting and Social Change, Elsevier Inc., Vol. 102, pp. 225-239.

Boons, F. and Lüdeke-Freund, F. (2013), "Business models for sustainable innovation: state-of-the-art and steps towards a research agenda", Journal of Cleaner Production, Vol. 45, pp. 9-19.

Boyer, K.K., Ward, P.T. and Leong, G.K. (1996), “Approaches to the factory of the future: an empirical taxonomy”, Journal of Operations Management, Vol. 14 No. 4, pp. 297-313.

Bryman, A. and Bell, E. (2015), Business Research Methods. Methods, 4th edition, Oxford University Press.

Bülbül, H., Ömürbek, N., Paksoy, T. and Bektaş, T. (2013), “An empirical investigation of advanced manufacturing technology investment patterns: evidence from a developing country", Journal of Engineering and Technology Management, Vol. 30 No. 2, pp. 136-156.

Chertow, M.R. (2007), “'Uncovering’ industrial symbiosis”, Journal of Industrial Ecology, Vol. 11 No. 1, pp. $11-30$.

Chesbrough, H. (2010), "Business model innovation: opportunities and barriers”, Long Range Planning, Vol. 43, pp. 354-363.

Chesbrough, H. and Rosenbloom, R.S. (2002), "The role of the business model in capturing value from innovation: evidence from Xerox Corporation's technology spin-off companies”, Industrial and Corporate Change, Vol. 11, pp. 529-555.

Copani, G. and Urgo, M. (2012), "New business models and configuration approaches for focused-flexibility manufacturing systems", 1st CIRP Global Web Conference: Interdisciplinary Research in Production Engineering, pp. $10-15$.

Foresight. (2013), The future of manufacturing: a new era of opportunity and challenge for the UK.

Giesen, E., Berman, S.J., Bell, R. and Blitz, A. (2007), “Three ways to successfully innovate your business model", Strategy \& Leadership, Vol. 35 No. 6, pp. 27-33.

Girotra, K. and Netessine, S. (2013), "OM forum — business model innovation for sustainability”, Manufacturing \& Service Operations Management, INFORMS, Vol. 15 No. 4, pp. 537-544.

Goedkoop, M.J., Van Halen, C.J.G., Te Riele, H.R.M. and Rommens, P.J.M. (1999), Product service systems , ecological and economic basics, Ecological and Economic Basics, The Hague, Netherlands.: Ministry of Environment,.

Hockerts, K. and Weaver, N. (2002), "Towards a theory of sustainable product service systems", INSEAD-CMER research workshop on sustainable product service systems.

Johannsdottir, L. (2014), "Transforming the linear insurance business model to a closed-loop insurance model: a case study of Nordic non-life insurers", Journal of Cleaner Production, pp. 341 - 355.

Jun, H., Kiritsis, D. and Xirouchakis, P. (2007), "Research issues on closed-loop PLM", Computers in Industry, Vol. 58 No. 8-9, pp. 855-868. 
Lüdeke-Freund, F. (2010), "Towards a conceptual framework of business models for sustainability", Environmental Management, Vol. 49 No. 0, pp. 1-28.

Magretta, J. (2002), "Why business models matter”, Harvard Business Review, Vol. 80 No. 5, pp. 86-92.

Martinez, V., Bastl, M., Kingston, J. and Evans, S. (2010), “Challenges in transforming manufacturing organisations into product-service providers", Transforming manufacturing organisations, Vol. 21 No. 4 , pp. 449-469.

Maussang, N., Zwolinski, P. and Brissaud, D. (2009), "Product-service system design methodology: from the PSS architecture design to the products specifications", Journal of Engineering Design, Vol. 20 No. 4, pp. 349-366.

Maxwell, D. and Van Der Vorst, R. (2003), "Developing sustainable products and services", Journal of Cleaner Production, Vol. 11 No. 8, pp. 883-895.

Miles, M. and Huberman, A. (1994), Qualitative data analysis: an expanded sourcebook (2nd ed.), Qualitative data analysis: An expanded sourcebook (2nd ed.).

Mont, O. (2002), "Clarifying the concept of product-service system", Journal of Cleaner Production, Vol. 10 No. 3, pp. 237-245.

Neely, A. (2007), “The servitization of manufacturing: an analysis of global trends", The 14th European Operation Management Association Conference, Ankara, Turkey, Vol. 1, pp. 1-10.

Nelson, J., Ishikawa, E. and Geaneotes, A. (2009), Developing inclusive business models, Harvard Kennedy School and International Finance Corporation, doi:10.1007/BF02957687.

Nidumolu, R., Prahalad, C.K. and Rangaswami, M.R. (2009), "Why sustainability is now the key driver of innovation”, Harvard Business Review, Vol. 87 No. 9.

Osterwalder, A. and Pigneur, Y. (2010), Business model generation: a handbook for visionaries, game changers, and challengers, Vol. 5.

PCAST. (2011), Report to the president on ensuring American leadership in advanced manufacturing.

Rana, P., Short, S. and Evans, S. (2013), D2.4 First stage prototype tools and methods, capable of being fully used by industrial partners, Sustainable value creation in manufacturing networks (SustainValue) project, 7th Research Framework Programme of the European Union, available at: http://www.sustainvalue.eu/publications.htm.

Reim, W., Parida, V. and Örtqvist, D. (2015), "Product-service systems (PSS) business models and tactics - a systematic literature review", Journal of Cleaner Production, Vol. 97, pp. 61-75.

Richardson, J. (2008), “The business model: an integrative framework for strategy execution”, Strategic Change, Vol. 17, pp. 133-144.

Roy, R. (2000), “Sustainable product-service systems”, Futures, Unknown, Vol. 32, pp. 289-299.

Schaltegger, S., Lüdeke-Freund, F. and Hansen, E. (2012), "Business cases for sustainability and the role of business model innovation", International Journal of Innovation and Sustainable Development, Vol. 6 No. 2, pp. 95-119.

Seddon, P.B., Lewis, G.P., Freeman, P. and Shanks, G. (2004), "The case for viewing business models as abstractions of strategy", Communications of the Association for Information Systems, Vol. 13 No. 1, pp. $427-442$.

Teece, D.J. (2010), "Business models, business strategy and innovation”, Long Range Planning, Vol. 43 No. 2-3, pp. 172-194.

Toossi, A. (2011), A value-centric decision making framework for maintenance services outsourcing, Cranfield University.

Tukker, A. (2004), "Eight types of product-service system: eight ways to sustainability? experiences from SusProNet", Business Strategy and the Environment, Vol. 13 No. 4, pp. 246-260.

Tukker, A. (2015), "Product services for a resource-efficient and circular economy - a review", Journal of Cleaner Production, pp. 76-91.

UNEP. (2009), Design for sustainability: a step-by-step approach. 
Velamuri, V.K., Bansemir, B., Neyer, A.K. and Möslein, K.M. (2013), "Product service systems as a driver for business model innovation: lessons learned from the manufacturing industry", International Journal of Innovation Management, Vol. 17 No. 1.

Wells, P. (2013), "Sustainable business models and the automotive industry: a commentary", IIMB Management Review, Vol. 25 No. 4, pp. 228-239.

Williams, A. (2006), "Product-service systems in the automotive industry: the case of micro-factory retailing", Journal of Cleaner Production, Vol. 14 No. 2, pp. 172-184.

Womack, J.P., Jones, D.T. and Roos, D. (1990), The machine that changed the world: the story of lean production, Simon \& Schuster Ltd.

Xerox Corporation. (2001), Environment, health and safety report, UK and USA Xerox Corportaion.

Yang, M. (2015), Sustainable value analysis for product-service systems, University of Cambridge.

Yang, M., Rana, P. and Evans, S. (2013), "Product service system ( PSS ) life cycle value analysis for sustainability", The 6th International Conference on Design and Manufacture for Sustainable Development (ICDMSD).

Yang, M., Vladimirova, D., Rana, P. and Evans, S. (2014), "Sustainable value analysis tool for value creation”, Asian Journal of Management Science and Applications.

Yin, R.K. (2009), Case study research: design and methods, (Bickman, L. and Rog, D.J.,Eds.)Essential guide to qualitative methods in organizational research, Applied Social Research Methods Series, Sage Publications, Vol. 5, doi:10.1097/FCH.0b013e31822dda9e.

Yip, G.S. (2004), “Using strategy to change your business model”, Business Strategy Review, Vol. 15 No. 2 , pp. 17-24.

Zott, C., Amit, R. and Massa, L. (2011), “The business model: recent developments and future research", Journal of Management, Vol. 37 No. 4, pp. 1019-1042. 